\title{
PEMODELAN RESPON OPTIMAL KEBIJAKAN MONETER TERHADAP STABILITAS SEKTOR PERUMAHAN DAN INFLASI DI INDONESIA
}

\author{
Ryan Juminta Anward, Handry Imansyah, \\ Syahrituah Siregar, dan Ruddy Syafruddin \\ Ilmu Ekonomi dan Studi Pembangunan, Fakultas Ekonomi dan bisnis, Universitas Lambung Mangkurat \\ email: ryananward@unlam.ac.id,mhandryiman@gmail.com, syahrisiregar@gmail.com, \\ ruddysyafruddin@gmail.com
}

\begin{abstract}
The experiences from global financial crisis have demonstrated that monetary policy needs to expand its goal, which is not only attached to the traditional goal of monetary policy (inflation) but also take asset prices into account. Structural Vector Autoregression (SVAR) with short-term restrictions is utilized in this study to identify the response and the impact of monetary policy on housing prices and inflation including other macroeconomic variables (output and exchange rate) in Indonesia, so that the monitary respond to the inflation level and price of houses in Indonesia can be identified. The data used in this study are based on quarterly data over the period 2005Q1-2015Q4. Simulation results from SVAR model show that the policy rate (BI rate) has significant impact on housing price and inflation. Monetary policy through changes in the BI rate responds rapidly to the shock of inflation, output and exchange rate but does not respond to the fluctuations in housing prices. The model developed in this study also indicates the ineffectiveness of monetary policy transmission in Indonesia.
\end{abstract}

\begin{abstract}
Abstrak: Pengalaman krisis keuangan global yang telah terjadi menunjukkan kebijakan moneter perlu untuk memperluas tujuannya, yakni tidak hanya terpaku terhadap tujuan tradisional kebijakan moneter (inflasi) namun juga memperhatikan harga asset. Struktural Vector Autoregression (SVAR) dengan restriksi jangka pendek digunakan dalam penelitian ini untuk mengidentifikasi respon dan dampak kebijakan moneter terhadap harga perumahan dan inflasi termasuk juga variabel makro ekonomi lainnya (output dan nilai tukar) di Indonesia, sehingga respon kebijakan moneter terhadap tingkat inflasi dan harga perumahan di Indonesia dalam jangka pendek dapat teridentifikasi. Data yang digunakan dalam penelitian ini adalah data triwulan selama periode 2001Q1-2005Q4. Hasil simulasi dari model SVAR menunjukkan suku bunga kebijakan (BI Rate) berdampak signifikan terhadap harga perumahan dan tingkat inflasi. Kebijakan moneter yang dilakukan melalui perubahan BI Rate merespon secara cepat terhadap shock inflasi, output dan nilai tukar namun tidak memberikan respon terhadap fluktuasi harga perumahan. Model yang dikembangkan dalam penelitian ini juga mengindikasikan kurang efektifnya transmisi kebijakan moneter di Indonesia.
\end{abstract}

Kata kunci: kebijakan moneter, harga perumaban, structural VAR

\section{Pendahuluan}

Sektor perumahan merupakan sektor penting dalam perekonomian. Selain sebagai kebutuhan pokok manusia, perumahan juga sebagai bentuk investasi bagi masyarakat. Di berbagai negara, perumahan menjadi salah satu bentuk komponen kekayaan terbesar bagi rumah tangga dimana rumah tangga lebih dominan dalam memegang aset fisik seperti properti atau perumahan dibandingkan dengan aset keuangan (Zhu, 2014). Dalam beberapa tahun terakhir terjadi perubahan kondisi sektor perumahan di Indonesia. Sektor perumahan dan properti lainnya mengalami pertumbuhan yang pesat disertai dengan trend kenaikan harga. Semakin tersedianya akses kepemilikan rumah melalui kredit bank merupakan pendorong pesatnya pertumbuhan sektor perumahan.

Meskipun tidak diikuti dengan penurunan secara mendadak dan menyebabkan terjadinya ketidakstabilan makroekonomi namun kenaikan harga perumahan di Indonesia yang berlangsung secara terus menerus menimbulkan kemungkinan bahwa dapat saja terjadi speculative bubble di sektor perumahan. Kenaikan harga perumahan seharusnya mencerminkan kondisi fundamental makrekonomi yang ada. Maraknya kredit kepemilikan rumah dapat berpotensi menyebabkan terjadinya krisis keuangan yang kemudian akan berdampak pada sektor riil. Pengalaman krisis keuangan global yang berasal dari krisis properti atau subprime mortgage di Amerika Serikat menunjukkan keterkaitan erat antara sektor perumahan dan stabilitas makroekonomi. Pergerakan harga perumahan menjadi variabel makroekonomi penting terkait dengan kondisi perekonomian terutama ketika terjadi fluktuasi harga perumahan yang relatif besar (Kivedal, 2013). Seperti halnya harga aset lainnya, harga perumahan terkait dengan tingkat suku bunga sehingga harga perumahan menjadi salah satu transmisi utama dalam mekanisme transmisi kebijakan moneter (Miskin, 2007). Harga perumahan juga berhubungan erat dengan pergerakan siklus bisnis yakni terhadap variabel- 
variabel riil seperti investasi dan konsumsi (Ahearne, 2005).

Terjadinya boom dan burst harga perumahan memiliki konsekuensi penting bagi kegiatan ekonomi riil dan berpotensi mengganggu stabilitas sistem keuangan. Taylor (2007) menunjukkan rendahnya suku bunga di US akibat kebijakan moneter yang longgar memberikan kontribusi terjadinya penggelembungan harga perumahan. Jika pembuat kebijakan melakukan kebijakan yang merespon fluktuasi harga perumahan maka pembentukan bubble dapat dicegah. Pasca krisis keuangan global, perekomian dunia mengalami kondisi new normal yang secara tidak langsung mempengaruhi lingkungan kebijakan moneter. Kondisi new normal tersebut menyebabkan suku bunga jangka penjang relatif rendah di berbagai negara, rendahnya suku bunga jangka panjang dapat menyebabkan harga perumahan terus mengalami kenaikan. Stabilitas harga atau tingkat inflasi yang rendah harus tetap menjadi tujuan utama kebijakan moneter. Namun pengalaman krisis yang telah terjadi menunjukkan bahwa stabilitas harga saja tidak cukup untuk menjaga stabilitas makroekonomi. Kebijakan moneter perlu untuk memperluas fokusnya yakni tidak hanya terpaku terhadap tujuan tradisional kebijakan moneter (tingkat inflasi) namun juga memperhatikan harga aset terutama perumahan atau properti. Sebagaimana dikemukakan oleh Bjørnland dan Jacobsen (2010) bahwa kebijakan moneter yang dilakukan oleh bank sentral akan lebih berhasil apabila kebijakan moneter yang dilakukan juga merespon terhadap harga aset seperti perumahan.

Penelitian-penelitian empiris yang telah dilakukan umumnya memfokuskan pada peranan sektor perumahan dalam mekanisme transmisi kebijakan moneter. Berbeda dengan penelitianpenelitian empiris yang telah ada, penelitian ini fokus mengenai hubungan jangka pendek antara kebijakan moneter, sektor perumahan dan tingkat inflasi. Penelitian ini bertujuan untuk mengidentifikasi respon kebijakan moneter terhadap tingkat inflasi dan harga perumahan di Indonesia dalam jangka pendek. Pemodelan untuk mengidentifikasi respon kebijakan moneter dan dampaknya terhadap harga perumahan dan inflasi dalam jangka pendek tentunya akan memberikan informasi bagaimana seharusnya kebijakan moneter dilakukan.

\section{Tinjauan Pustaka}

Secara konvensional kebijakan moneter memiliki dua tujuan utama yaitu stabilitas harga dan output, dengan lebih menitikberatkan kepada tujuan stabilitas harga. Taylor rule yang dikemukan oleh Taylor (1993) selama ini digunakan sebagai benchmark oleh bank-bank sentral dalam melakukan. kebijakan moneter. Taylor rule menunjukkan bagaimana seharusnya bank sental menetapkan tingkat suku bunga dalam merespon kondisi inflasi dan output. Bentuk standar persamaan Taylor rule adalah sebagai berikut:

$$
\mathrm{I}=\mathrm{i}^{*}+\pi+\mathrm{a}\left(\pi-\pi^{*}\right)+\mathrm{b}\left(\mathrm{Y}-\mathrm{Y}^{*}\right)
$$

Dimana I merupakan suku bunga nominal kebijakan bank sentral, i* adalah suku bunga ekuilibrium riil, $\pi$ adalah tingkat inflasi, $\pi^{*}$ adalah target inflasi, $\mathrm{Y}$ adalah output, $\mathrm{Y}^{*}$ adalah output potensial dan a dan b adalah bobot pada inflation gap dan output gap. Secara umum persamaan Taylor rule menunjukkan bahwa suku bunga kebijakan bank sentral akan meningkat apabila tingkat inflasi berada di atas target inflasi yang ditetapkan bank sentral dan atau apabila tingkat output berada di atas output potensialnya. Apabila tingkat inflasi sudah berada pada targetnya dan output berada pada tingkat output potensial maka suku bunga kebijakan bank sentral ditetapkan pada tingkat suku bunga ekuilibrium. Menurut Taylor, pembuat kebijakan tidak secara otomatis mengikuti formula tersebut, namun memerlukan judgement dalam mengambil keputusan. Sebagaimana yang dikemukakan oleh Kohn (2007) bahwa kompleksitas perekonomian memerlukan berbagai macam indikator dan informasi untuk memproyeksi perubahan tingkat inflasi dan aktivitas perekonomian terutama perubahan kondisi yang bersifat cepat dan tidak lazim.

Dalam beberapa tahun terakhir literatur kebijakan moneter memfokuskan peran harga aset dalam kebijakan moneter. Adanya bukti kuat secara luas bahwa harga aset kerap kali mengalami bubble dari waktu ke waktu dan berakibat menyebabkan terjadinya distrosi dan instabilitas dalam perekonomian. Sehingga banyak ahli yang berpendapat bahwa kebijakan moneter yang optimal perlu merespon terhadap harga aset. Literatur sebelumnya lebih banyak memfokuskan keterkaitan kebijakan moneter dengan harga saham, namun sejak terjadinya krisis keuangan global yang dipicu oleh subprime mortgage di US, fokus kajian beralih ke harga aset perumahan. Finocchiaro dan Heideken (2012) menyatakan bahwa harga aset perumahan lebih rentan dampaknya terhadap perekonomian dibandingkan harga aset lainnya. Fluktuasi harga perumahan berpotensi besar dalam mempengaruhi aggregat pengeluaran karena rumah merupakan bentuk kekayaan rumah tangga dan proporsi besar dari aset bank menggunakan perumahan sebagai jaminan. Selain itu juga harga perumahan dapat memberikan prediksi terhadap tingkat inflasi dan output lebih baik dibandingkan harga saham. 
Finocchiaro dan Heideken (2012) dalam kajiannya terhadap bank sentral di US, Inggris dan Jepang mengestimasi Taylor rule dengan penambahan variabel harga perumahan. Hasil kajian mereka menyatakan bahwa pergerakan harga perumahan merupakan elemen yang terpisah dalam fungsi reaksi kebijakan moneter yang dilakukan oleh bank-bank sentral tersebut. Hasil kajian mereka juga menunjukkan meskipun dalam target output dan inflasi yang ketat, kebijakan moneter yang merespon perubahan terhadap harga perumahan tetap optimal. Beberapa kajian menyarankan bahwa bank sentral tidak hanya menggunakan harga aset sebagai bagian dari informasi untuk menaksir tingkat inflasi dan output kedepan namun juga sebagai elemen dalam fungsi reaksi kebijakan moneter (Cecchetti et al, 2000; Borio dan Lowe, 2002; Filardo, 2004). Penggelembungan harga aset akan menyebabkan terjadinya pertumbuhan konsumsi dan investasi yang berlebihan sehingga menggangu stabilitas makroenomi terkait dengan tingginya variabilitas output dan inflasi. Perubahan suku bunga kebijakan bank sentral diperlukan untuk mengimbangi deviasi harga aset dari harga fundamentalnya agar dapat mengurangi potensi terjadinya pembentukan bubble.

Akram et al (2005) membandingkan respon kebijakan moneter konvensional dengan respon kebijakan moneter yang turut memasukkan harga aset. Hasil yang diperoleh menunjukkan bahwa respon kebijakan moneter yang mengakomodasi perubahan harga perumahan dan harga saham lebih meningkatkan performa makroekonomi. Kontikas dan Mantagnoli (2005) dalam kajiannya menyatakan bahwa kebijakan moneter seharusnya merespon terhadap perubahan harga asset dari harga fundamentalnya, dengan tingkat respon tergantung dari peranan harga asset dalam transmisi kebijakan moneter dan sumber pergerakan harga aset tersebut. Notarpietro dan Siviero (2014) melakukan investigasi efektivitas kebijakan moneter dengan memasukkan harga perumahan sebagai salah satu tujuan bank sentral dengan asumsi adanya friksi keuangan. Hasil kajian mereka menunjukkan respon kebijakan moneter yang memaksimumkan social welfare memerlukan reaksi terhadap variasi harga perumahan, dengan tanda dan arah respon tergantung dari kondisi friksi keuangan dalam perekonomian. Secara konseptual dan empiris hasil kajian literatur menyatakan bahwa kebijakan moneter semestinya "lean against the wind" yaitu menaikkan suku bunga melampai tingkat yang diperlukan untuk menjaga stabilitas harga selama jangka pendek dan menengah ketika terjadi potensi bubble atau sebaliknya ketika terjadi burst. Dengan kata lain, kebijakan moneter yang lebih ketat dibandingkan standar Taylor rule ketika terjadi potensi boom dan kebijakan moneter yang lebih longgar dibandingkan standar Taylor rule ketika terjadi potensi burst.

Dalam literatur, keterkaitan antara kebijakan moneter dan harga perumahan dijelaskan melalui transmisi kebijakan moneter jalur harga aset. Terdapat jalur langsung dan jalur tidak langsung bagaimana kebijakan moneter melalui perubahan suku bunga mempengaruhi harga perumahan dan kegiatan perekonomian riil (Mishkin, 2007). Secara langsung melalui jalur biaya modal pengguna (user cost of capitah), jalur ekspektasi dan jalur penawaran. Sedangkan secara tidak langsung melalui jalur kekayaan, jalur kredit, dan jalur neraca rumah tangga.

Kajian-kajian empiris mengenai keterkaitan kebijakan moneter dan sektor perumahan telah dilakukan pada level regional, nasional maupun cross countries. Aoki et al (2002) mengestimasi dampak kebijakan moneter terhadap harga perumahan di UK dengan model Vector Autoregression (VAR). Variabel yang digunakan sebanyak delapan variabel yakni output, inflasi, harga minyak, jumlah uang beredar, suku bunga jangka pendek, konsumsi, harga perumahan dan investasi perumahan. Hasil kajian mereka menunjukkan shock positif dari suku bunga jangka pendek sebesar 50 basis point akan mempengengaruhi harga perumahan sebesar 80 basis point pada kuartal kelima. Elbourne (2008) juga mengidentifikasi peran sektor perumahan terkait kebijakan moneter di UK dengan menggunakan menggunakan model Structural Vector Autoreggresion (SVAR). Hasil kajiannya menunjukkan peran transmisi kebijakan moneter melalui sektor perumahan relatif kecil. Diperoleh hasil kenaikan suku bunga jangka pendek menyebabkan turunnya harga perumahan, tingkat inflasi, dan penjualan ritel. Sedangkan kenaikan harga rumah menyebabkan meningkatnya konsumsi, tingkat inflasi dan suku bunga. Jarociński et al (2008) dengan menggunakan model Bayesian Vector Autoregression (BVAR) mengkaji keterkaitan kebijakan moneter dan sektor perumahan di US. Variabel yang digunakan adalah real GDP, GDP deflator, harga komoditas, federal fund rate, M2, konsumsi riil, harga perumahan riil dan spread suku bunga jangka panjang. Hasil kajian mereka menunjukkan kebijakan moneter berdampak signifikan terhadap harga perumahan dan investasi perumahan. Sedangkan Phiri (2016) mengidentifikasi efek kebijakan moneter terhadap harga perumahan melalui Momentum Threshold Autoregressive Model dan Threshold Trror Correction Model (MTAR-TECM) di Afrika Selatan. Hasil analisa yang dilakukan menunjukkan hubungan 
negatif yang signifikan dari suku bunga ke harga perumahan namun dampaknya relatif kecil.

Kajian pada tingkat regional dan nasional dilakukan oleh Vargas-Silva (2008) mengenai keterkaitan kebijakan moneter dan sektor perumahan di US. Dengan menggunakan Structural Vector Autoregression (SVAR) melalui identifikasi pembatasan tanda (sign restriction), hasil kajiannya menunjukkan pembangunan perumahan dan investasi perumahan merespon negatif terhadap kebijakan moneter kontraktif. Pada level cross countries, Iacoviello dan Minetti (2008) mengidentifikasi fluktuasi harga perumahan di empat negara Eropa dengan menggunakan model Vector Error Correction (VECM). Estimasi VECM yang dilakukan menunjukkan kenaikan suku bunga menyebabkan turunnya harga perumahan dan GDP. Kajian pada level cross countries lainnya dilakukan oleh Sá et al (2010) yakni pada negaranegara OECD. Hasil model panel VAR yang mereka estimasi menunjukkan kebijakan moneter ekspansif berdampak positif dan signifikan terhadap harga perumahan, kredit riil dan invetasi perumahan. Sebagian besar kajian empiris menunjukkan terdapat keterkaitan antara kebijakan moneter dan harga perumahan. Seperti kajian lainnya yang dilakukan oleh Lastrapes (2002), Pariès et all (2008), Tan dan Chen (2013), McDonald dan Stokes (2014) dan Liu dan Liu (2012).

\section{Metode Penelitian}

Jenis data yang digunakan dalam penelitian ini adalah data time series yang diperoleh dari Bank Indonesia dan IMF International Financial Statistic (IFS). Data yang digunakan adalah data kuartal dari periode 2005Q1 hingga 2015Q4. Periode yang digunakan ditentukan berdasarkan ketersediaan data. Data yang digunakan adalah Residential Property Price Index (RPPI), Real Gross Domestic Product (GDP riil), BI Rate, Consumer Price Index (CPI) dan nilai tukar (Rupiah terhadap US Dollar).

Untuk mengidentifikasi respon kebijakan moneter serta pengaruhnya terhadap tingkat inflasi dan harga perumahan dalam penelitian ini dikembangkan model Structural Vector Autoregression (SVAR). Model SVAR adalah pengembangan dari model Vector Autoregression (VAR). Kelemahan utama model VAR adalah tidak berlandaskan teori yang kuat. Kelemahan model VAR tersebut dapat diatasi melalui model SVAR yaitu melalui penetapan restriksi atau pembatasan dalam sistem persamaan. Restriksi tersebut bertujuan untuk memisahkan pergerakan variabel endogen ke dalam beberapa komponen dalam sistem persamaan dengan mengacu pada suatu teori.

Estimasi model SVAR didahului dengan pengujian stationaritas seluruh variabel. Dalam analisis time series, informasi tentang stasioneritas suatu data merupakan hal yang sangat penting. Mengikutsertakan variabel yang nonstasioner ke dalam persamaan estimasi akan menghasilkan kesimpulan yang tidak benar karena koefisien regresi tidak efisien. Pada penelitian ini uji stasionaritas dilakukan dengan menggunakan metode Augmented Dickey-Fuller (ADF) dan PhillipsPerron (PP). Penentuan lag optimal menjadi salah satu prosedur penting yang harus dilakukan dalam pembentukan model SVAR (Enders, 2004). Terdapat kriteria informasi untuk menentukan jumlah lag optimal yakni Akaike Information Criterion (AIC), Schwartr. Criterion (SC), Hannan-Quinn Criterion (HQ), Likelibood Ratio (LR) dan Final Predictor Error (FPE). Dalam kajian ini, penentuan jumlah lag optimal ditentukan berdasarkan lag yang dipilih oleh kriteria informasi terbanyak. Pengujian kontegrasi melalui uji kointegasi Johansen juga dilakukan dalam penelitian ini untuk mengetahui hubungan jangka panjang antar variabel.

Langkah awal dalam model SVAR adalah menentukan variabel-variabel endogen dalam sistem persamaan. Kajian ini menggunakan lima variabel, yang merupakan bentuk skala kecil model SVAR. Dalam penelitian ini spesifikasi vektor endogen sebagai berikut :

[ RPPI, RGDP, CPI, IR, PC, ER ]

Secara spesifik persamaan dalam bentuk VAR sebagai berikut :

$$
\begin{aligned}
\text { BIRATE }_{t}=\alpha_{1} & +\sum_{J=1}^{n} \beta_{1 j} \text { BIRATE }_{t-j}+\sum_{J=1}^{n} \theta_{1 j} C P I_{t-j}+\sum_{J=1}^{n} \varphi_{1 j} R P P I_{t-j} \\
& +\sum_{J=1}^{n} \gamma_{1 j} R G D P_{t-j}+\sum_{J=1}^{n} \delta_{1 j} E R_{t-j}+\epsilon_{1 t}
\end{aligned}
$$




$$
\begin{aligned}
C P I_{t}=\alpha_{2}+ & \sum_{J=1}^{n} \beta_{2 j} C P I_{t-j}+\sum_{J=1}^{n} \theta_{2 j} B I R A T E_{t-j}+\sum_{J=1}^{n} \varphi_{2 j} R P P I_{t-j}+\sum_{J=1}^{n} \gamma_{2 j} R G D P_{t-j} \\
& +\sum_{J=1}^{n} \delta_{2 j} E R_{t-j}+\epsilon_{2 t} \\
R P P I_{t}=\alpha_{3}+ & \sum_{J=1}^{n} \beta_{3 j} R P P I_{t-j}+\sum_{J=1}^{n} \theta_{3 j} B I R A T E_{t-j}+\sum_{J=1}^{n} \varphi_{3 j} C P I_{t-j}+\sum_{J=1}^{n} \gamma_{3 j} R G D P_{t-j} \\
& +\sum_{J=1}^{n} \delta_{3 j} E R_{t-j}+\epsilon_{3 t} \\
R G D P_{t}=\alpha_{4}+ & \sum_{J=1}^{n} \beta_{4 j} R G D P_{t-j}+\sum_{J=1}^{n} \theta_{4 j} B I R A T E_{t-j}+\sum_{J=1}^{n} \varphi_{4 j} C P I_{t-j}+\sum_{J=1}^{n} \gamma_{4 j} R P P I_{t-j} \\
& +\sum_{J=1}^{n} \delta_{4 j} E R_{t-j}+\epsilon_{4 t} \\
& +\sum_{J=1}^{n} \delta_{5 j} R G D P_{t-j}+\epsilon_{5 t} \beta_{5 j} E R_{t-j}+\sum_{J=1}^{n} \theta_{5 j} B I R A T E_{t-j}+\sum_{J=1}^{n} \varphi_{5 j} C P I_{t-j}+\sum_{J=1}^{n} \gamma_{5 j} R P P I_{t-j} \\
E R_{t}=\alpha_{5}+\sum_{j=1} &
\end{aligned}
$$

Dimana RPPI adalah Residential Property Price Index sebagai proksi harga perumahan, RGDP adalah real Gross Domestic Product sebagai proksi output, CPI adalah Consumer Price Index sebagai proksi tingkat inflasi, IR adalah suku bunga kebijakan (BI Rate) sebagai proksi kebijakan moneter dan ER adalah nilai tukar rupiah terhadap dollar. Spesifikasi reduced form VAR sebagai berikut:

$$
\mathrm{Y}_{\mathrm{t}}=\mathrm{C}_{1} \mathrm{Y}_{\mathrm{t}-1}+\ldots \mathrm{C}_{\mathrm{p}} \mathrm{Y}_{\mathrm{t}-\mathrm{p}}+\mathrm{e}_{\mathrm{t}}
$$

Dimana $Y_{t}$ merupakan vektor variabel endogen (nx1), $C_{1}$ adalah vektor (nx1) intersep, $C_{i}$ ke $C_{p}$ adalah matriks (nxn) lag variabel endogen dan $e_{t}$ adalah vektor (nx1) error term. Model SVAR memasukkan sejumlah restriksi yang diidentifikasi. Spesifikasi SVAR dalam kajian ini dapat dinyatakan sebagai berikut :

$$
\mathrm{A}_{0} \mathrm{Y}_{\mathrm{t}}=\mathrm{A}(\mathrm{L}) \mathrm{X}_{\mathrm{t}-1}+\mathrm{B} \varepsilon_{\mathrm{t}}
$$

Dimana $Y_{t}$ merupakan vektor variabel endogen (nx1), $\mathrm{A}_{0}$ adalah contemporaneous relations antar variabel, $A(L)$ adalah matriks polynomial (finite order matrix) dengan operator lag L, B adalah matrik dengan diagonal bukan nol dan $\varepsilon_{\mathrm{t}}$ adalah vektor struktural disturbance. Koefisien dalam matriks pada persamaan diatas di atas tidak diketahui dan setiap variabel memiliki efek kontemporer (contemporaneous effect) sehingga diperlukan identifikasi restriksi dalam persamaan di atas. Untuk menetapkan restriksi dalam model SVAR terdapat beberapa cara seperti short run restriction, long run restriction dan sign restriction.
Penelitian ini menggunakan short run restriction sesuai dengan tujuan penelitian. Jumlah restriksi yang digunakan sebanyak 11 restriksi sehingga sistem persamaan menjadi over identified. Restriksi dilakukan berdasarkan teori, hasil-hasil kajian empiris dalam literatur dan tujuan penelitian. Untuk memastikan validitas model SVAR dilakukan pengujian Roots of Characteristic Polynomial, yakni suatu sistem VAR dikatakan stabil jika seluruh roots memiliki nilai absolute kurang dari 1. Uji LM test juga dilakukan untuk mendeteksi masalah autokorelasi dalam model SVAR yang dikembangkan. Selanjutnya untuk melakukan analisa, dilakukan analisa impulse response function (IRF) dan variance decomposition. IRF menunjukkan bagaimana respon dari setiap variabel endogen sepanjang waktu terhadap shock dari variabel itu sendiri dan variabel endogen lainnya. IRF melihat pengaruh kontemporer dari sebuah variabel dependen jika mendapatkan shock dari variabel independen sebesar satu standar deviasi. Sedangkan analisis dekomposisi varian (DFEV) digunakan untuk menganalisis seberapa besar pengaruh random shock dari variabel tertentu terhadap variabel endogen.

\section{Hasil dan Pembahasan}

Berdasarkan hasil uji Augmented Dickey Fuller (ADF) dan Uji Phillips-Perron (PP) seluruh variabel tidak stationer dalam bentuk level $\mathrm{I}(0)$ atau terdapat unit root. Sedangkan pengujian pada tingkat first 
difference $\mathrm{I}(1)$ menunjukkan bahwa seluruh variabel stasioner atau tidak terdapat unit root. Dari hasil uji stationeritas maka persamaan SVAR yang diestimasi adalah dalam bentuk first difference.

Tabel 1 Hasil Uji Stationaritas

\begin{tabular}{ccccccccc}
\hline \multirow{2}{*}{ Variabel } & \multicolumn{4}{c}{ ADF Test } & \multicolumn{4}{c}{ PP Test } \\
\cline { 2 - 9 } & \multicolumn{2}{c}{ Level } & \multicolumn{3}{c}{ First Difference } & Level & First Difference \\
\hline t-stat & Prob. & t-stat & Prob. & t-stat & Prob. & t-stat & Prob. \\
\hline CPI & -3.433553 & 0.0605 & -5.663837 & 0.0002 & -2.926427 & 0.1647 & -5.488251 & 0.0003 \\
\hline ER & -1.523093 & 0.8056 & -5.455406 & 0.0003 & -0.750500 & 0.9623 & -4.423425 & 0.0055 \\
\hline IR & -3.423783 & 0.0618 & -3.401949 & 0.0164 & -2.429891 & 0.3598 & -2.940851 & 0.0492 \\
\hline RGDP & -2.538399 & 0.3092 & -7.006472 & 0.0000 & -2.558983 & 0.3001 & -6.987319 & 0.0000 \\
\hline RPPI & -0.961684 & 0.9388 & -5.881028 & 0.0001 & -1.111753 & 0.9152 & -5.881028 & 0.0001 \\
\hline
\end{tabular}

Sumber : hasil olah data

Pengujian jumlah lag optimal dilakukan dalam bentuk first difference yang diestimasi melalui model
VAR. Hasil pengujian jumlah lag optimal adalah sebagai berikut.

Table 2 Hasil Pengujian Lag Optimal

\begin{tabular}{ccccccc}
\hline Lag & LogL & LR & FPE & AIC & SC & HQ \\
\hline 0 & -527.9643 & NA & 510005.0 & 27.33150 & $27.54478^{*}$ & 27.40803 \\
\hline 1 & -495.4968 & 54.94507 & 352033.6 & 26.94855 & 28.22822 & $27.40769^{*}$ \\
\hline 2 & -466.7016 & 41.34701 & 309626.1 & 26.75393 & 29.09997 & 27.59567 \\
\hline 3 & -441.4854 & 29.74211 & 365890.1 & 26.74284 & 30.15528 & 27.96719 \\
\hline 4 & -399.5949 & $38.66821^{*}$ & $224700.4^{*}$ & $25.87666^{*}$ & 30.35548 & 27.48362 \\
\hline
\end{tabular}

Sumber : hasil olah data

Berdasarkan tabel di atas dengan memasukkan jumlah lag 4 (berdasarkan pertimbangan jumlah observasi), jumlah lag optimal menurut kriteria LR, FPE dan AIC adalah 4. Dalam penelitian ini jumlah lag optimal ditetapkan sebanyak 4 yaitu berdasarkan kriteria LR, FPE dan AIC.
Pengujian kointegrasi diperlukan untuk mengetahui apakah terdapat hubungan jangka panjang antar variabel dalam model SVAR. Pengujian kointegrasi dilakukan dengan menggunakan uji kointegrasi johansen melalui nilai Trace Statistic dan Maximum Eigenvalue.

Tabel 3 Hasil Uji Kointegrasi Johansen

\begin{tabular}{|c|c|c|c|c|}
\hline \multicolumn{5}{|c|}{ Unrestricted Cointegration Rank Test (Trace) } \\
\hline Hypothesized & & Trace & 0.05 & \\
\hline No. of $\mathrm{CE}(\mathrm{s})$ & Eigenvalue & Statistic & Critical Value & Prob.** \\
\hline None* & 0.585313 & 89.11724 & 69.81889 & 0.0007 \\
\hline At most $1 *$ & 0.471321 & 52.14750 & 47.85613 & 0.0187 \\
\hline At most 2 & 0.354194 & 25.37783 & 29.79707 & 0.1484 \\
\hline At most 3 & 0.111890 & 7.013057 & 15.49471 & 0.5761 \\
\hline At most 4 & 0.047169 & 2.029361 & 3.841466 & 0.1543 \\
\hline
\end{tabular}

\begin{tabular}{ccccc}
\hline \multicolumn{5}{c}{ Unrestricted Cointegration Rank Test (Maximum Eigenvalue) } \\
\hline Hypothesized & & Max-Eigen & 0.05 & \\
\hline No. of CE $(\mathrm{s})$ & Eigenvalue & Statistic & Critical Value & Prob.** \\
\hline None & 0.585313 & 36.96974 & 33.87687 & 0.0207 \\
\hline At most 1 & 0.471321 & 26.76967 & 27.58434 & 0.0633 \\
\hline At most 2 & 0.354194 & 18.36478 & 21.13162 & 0.1168 \\
\hline At most 3 & 0.111890 & 4.983695 & 14.26460 & 0.7439 \\
\hline At most 4 & 0.047169 & 2.029361 & 3.841466 & 0.1543 \\
\hline
\end{tabular}


Hasil dari Trace Statistic menunjukkan terdapat dua kointegrasi vektor, sedangkan dari hasil Maximum Eigenvalue terdapat satu kointegrasi vektor. Hasil ini menunjukkan terdapat hubungan jangka panjang antar variabel-variabel yang diestimasi dalam model SVAR.

Hasil pengujian stabilitas model menunjukkan semua root bernilai kurang dari 1 atau berada dalam unit circle sehingga model SVAR yang digunakan dapat dinyatakan stabil. Untuk memastikan tidak terdapat masalah autokorelasi dalam model SVAR yang diestimasi dilakukan uji autokorelasi LM test. Hasil uji LM test menunjukkan dari lag 1 sampai dengan lag 12 diperoleh nilai probabilitas yang lebih besar dari tingkat signifikansi 5\% sehingga model SVAR yang digunakan dapat dinyatakan terbebas dari masalah autokorelasi.

Hasil estimasi untuk pengaruh antar variabel ditunjukkan oleh masing-masing koefisien variabel yang berada dalam bentuk matriks. Hasil estimasi SVAR adalah sebagai berikut.

Table 4 Hasil Estimasi SVAR

\begin{tabular}{|c|c|c|c|c|}
\hline \multicolumn{5}{|l|}{$A=$} \\
\hline 1 & 0 & 0 & 0 & 0 \\
\hline 0 & 1 & 0 & 0 & 0 \\
\hline 0 & 0 & 1 & 0 & 0 \\
\hline 0 & 0 & 0 & 1 & 0 \\
\hline 0 & 0 & 0 & 0 & 1 \\
\hline \multicolumn{5}{|l|}{$\mathrm{B}=$} \\
\hline 1 & $\mathrm{C}(2)$ & $C(4)$ & $\mathrm{C}(8)$ & 0 \\
\hline 0 & 1 & $C(5)$ & 0 & 0 \\
\hline $\mathrm{C}(1)$ & $C(3)$ & 1 & $C(9)$ & $C(11)$ \\
\hline 0 & 0 & $C(6)$ & 1 & 0 \\
\hline \multirow[t]{2}{*}{0} & 0 & $C(7)$ & $C(10)$ & 1 \\
\hline & Coefficient & Std. Error & z-Statistic & Prob. \\
\hline $\mathrm{C}(1)$ & 0.417500 & 0.032725 & 12.75778 & 0.0000 \\
\hline $\mathrm{C}(2)$ & 1.350842 & 0.236800 & 5.704559 & 0.0000 \\
\hline $\mathrm{C}(3)$ & 0.173231 & 0.077971 & 2.221731 & 0.0263 \\
\hline $\mathrm{C}(4)$ & 3.136394 & 0.145742 & 21.52022 & 0.0000 \\
\hline $\mathrm{C}(5)$ & -553.4733 & 47.04357 & -11.76512 & 0.0000 \\
\hline $\mathrm{C}(6)$ & 1.160858 & 0.090931 & 12.76631 & 0.0000 \\
\hline $\mathrm{C}(7)$ & 2.838003 & 0.236965 & 11.97645 & 0.0000 \\
\hline $\mathrm{C}(8)$ & 2.445320 & 0.269197 & 9.083759 & 0.0000 \\
\hline $\mathrm{C}(9)$ & 0.662946 & 0.072447 & 9.150725 & 0.0000 \\
\hline $\mathrm{C}(10)$ & 1.716896 & 0.160128 & 10.72199 & 0.0000 \\
\hline $\mathrm{C}(11)$ & 0.015381 & 0.037202 & 0.413430 & 0.6793 \\
\hline
\end{tabular}

Sumber: hasil olah data

Nilai koefisien $C(1), C(3), C(9)$ dan $C(11)$ yang merupakan komponen matriks dari baris ketiga menunjukkan pengaruh variabel tingkat inflasi, nilai tukar, output dan tingkat harga perumahan terhadap BI Rate. Nilai koefisien C(2), C(4), dan $\mathrm{C}(8)$ yang merupakan komponen matriks dari baris pertama menunjukkan pengaruh variabel nilai tukar, BI Rate dan output terhadap tingkat inflasi. Nilai koefisien $C(7)$ dan $C(10)$ yang merupakan komponen matriks dari baris kelima yang menunjukkan pengaruh BI rate dan output terhadap harga perumahan. Nilai koefisien C(5) yang merupakan komponen matriks dari baris pertama menunjukkan pengaruh BI rate terhadap tingkat nilai tukar. Nilai koefisien $\mathrm{C}(6)$ yang merupakan komponen matriks dari baris keempat menunjukkan pengaruh BI rate terhadap output.

Berdasarkan hasil estimasi SVAR tersebut, hampir seluruh variabel yang digunakan sebagai inovasi dari restriksi dalam model secara statistik berpengaruh signifikan terhadap variabel lain. Hanya variabel harga perumahan yang secara statistik tidak signifikan dalam mempengaruhi BI Rate. Hal ini mengindikasikan kebijakan moneter yang dilakukan oleh Bank Indonesia melalui 
perubahan BI Rate tidak merespon terhadap perubahan tingkat harga perumahan.

\section{A. Respon BI Rate Terhadap Tingkat Inflasi dan Harga Perumahan}

Hasil Structural Impulse Response Function (IRF) yang menggambarkan respon BI Rate terhadap perubahan tingkat inflasi (D(CPI)), harga perumahan (D(RPPI)), output (D(RGDP)) dan nilai tukar (D(ER)) ditunjukkan dalam Gambar 1.

Gambar 1 Impulse Response Function Respon BI Rate
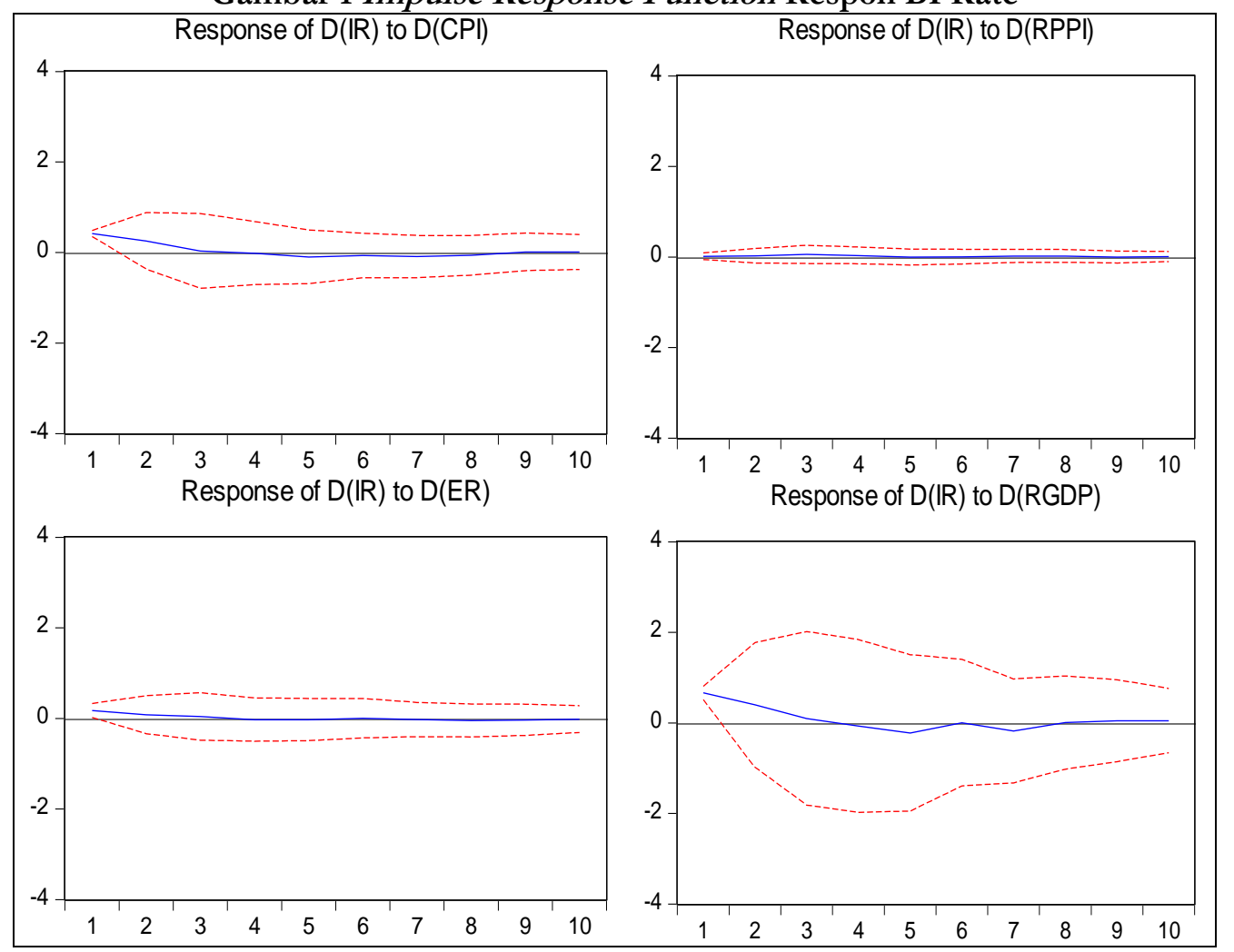

Respon BI Rate terhadap peningkatan satu standar deviasi variabel CPI menunjukkan respon positif. Ketika terjadi kenaikan tingkat inflasi maka BI Rate akan meningkat hingga periode triwulan ke 3 dan kemudian mencapai netral pada periode twirulan ke 4. Hasil ini menunjukkan bahwa BI Rate atau kebijakan moneter yang dilakukan Bank Indonesia responsif terhadap perubahan tingkat inflasi. Hasil IRF menunjukkan perubahan tingkat harga perumahan tidak direspon oleh BI Rate, dimana impulse response menunjukkan pergerakan yang berada titik 0 atau keseimbangan (convergence) dari periode 1 sampai periode 10 . Hasil ini menunjukkan bahwa BI Rate atau kebijakan moneter yang selama ini dilakukan oleh Bank Indonesia tidak merespon terhadap perubahan harga perumahan. BI Rate merespon positif kenaikan nilai tukar (pelemahan Rupiah), ketika terjadi pelemahan nilai Rupiah maka BI Rate akan meningkat dari periode triwulan ke 1 sampai triwulan ke 3 dan mencapai netral pada

triwulan ke 4. Hasil impulse response juga menunjukkan respon positif BI Rate terhadap kenaikan ouput. Kenaikan output akan menyebabkan kenaikan BI Rate sampai periode triwulan ke 3 dan pada triwulan ke 4 bersifat netral. Secara umum hasil structural impulse response function menunjukkan kebijakan moneter yang dilakukan oleh Bank Indonesia melalui perubahan BI Rate responsif terhadap shock variabel inflasi, output dan nilai tukar. Namun kebijakan moneter yang selama ini dilakukan tidak merespon terhadap perubahan tingkat harga perumahan.

Structural variance decomposition digunakan untuk mengetahui variabel mana yang paling berperan penting dalam menjelaskan perubahan suatu variabel. Faktorisasi yang digunakan dalam analisa variance decomposition adalah structural decomposition. Tabel 5 menunjukan persentase variasi dari BI Rate oleh shock variabel-variabel dalam sistem persamaan. 
Tabel 5 Variance Decomposition Respon BI Rate

\begin{tabular}{ccccccc}
\hline \multirow{2}{*}{ Periode } & S.E. & \multicolumn{2}{c}{ Shock D(CPI) Shock D(ER) } & Shock D(IR) & $\begin{array}{c}\text { Shock } \\
\text { D(RGDP) }\end{array}$ & $\begin{array}{c}\text { Shock } \\
\text { D(RPPI })\end{array}$ \\
\hline 1 & 4.317561 & 10.60225 & 1.825319 & 60.82542 & 26.73262 & 0.014389 \\
\hline 2 & 4.980571 & 8.297994 & 1.264885 & 69.70087 & 20.70571 & 0.030541 \\
\hline 3 & 5.062238 & 8.139554 & 1.290724 & 69.89148 & 20.54477 & 0.133476 \\
\hline 4 & 5.126639 & 8.125966 & 1.314536 & 69.73596 & 20.65586 & 0.167682 \\
\hline 5 & 5.701702 & 7.877341 & 1.252405 & 69.86982 & 20.84327 & 0.157156 \\
\hline 6 & 5.780986 & 7.977432 & 1.245642 & 69.89314 & 20.72725 & 0.156533 \\
\hline 7 & 5.784446 & 8.044475 & 1.238753 & 69.30918 & 21.24029 & 0.167305 \\
\hline 8 & 5.786097 & 8.121122 & 1.301014 & 69.26975 & 21.12838 & 0.179735 \\
\hline 9 & 5.910556 & 8.085923 & 1.327834 & 69.31988 & 21.08728 & 0.179080 \\
\hline 10 & 5.917802 & 8.073655 & 1.334815 & 69.29482 & 21.11605 & 0.180660 \\
\hline Sumber : hasil olah data & & & & &
\end{tabular}

Hasil variance decomposition terhadap BI Rate menunjukan bahwa varian variabel BI Rate sendiri masih memberikan pengaruh yang dominan, dengan kontribusi berkisar 60\%-70\% (dari periode 1 sampai periode 10). Variabel yang memberikan kontribusi signifikan terhadap varian BI Rate adalah variabel output. Perubahan variabel output lebih berperan dalam menjelaskan perubahan BI Rate dibandingkan variabel inflasi dan nilai tukar. Perubahan variabel output dapat menjelaskan sekitar 20\%$37 \%$ varian BI Rate. Variabel inflasi yang merupakan tujuan utama kebijakan moneter Bank Indonesia juga memberikan kontribusi yang cukup signifikan terhadap varian BI Rate, dengan besaran varian antara 7\%-11\%. Pengaruh variabel nilai tukar terhadap varian BI Rate relatif kecil yakni berkisar antara 1\%-2\% dari periode 1 sampai periode 10 . Sedangkan variabel tingkat harga perumahan relatif tidak memberikan pengaruh terhadap varian BI Rate.
Besarnya respon BI Rate terhadap output menunjukkan bahwa kebijakan pengendalian inflasi yang ditempuh oleh Bank Indonesia fokus dalam pengelolaan tekanan inflasi yang berasal dari sisi permintaan atau output gap dibandingkan dengan tekanan inflasi yang bersifat temporer. Hasil ini juga mengindikasikan keyakinan Bank Indonesia bahwa transmisi kebijakan moneter melalui jalur suku bunga perbankan dan jalur kredit lebih efektif dibandingkan dengan jalur nilai tukar, jalur harga aset dan jalur ekspektasi.

B. Dampak BI Rate Terhadap Tingkat Inflasi dan Harga Perumahan

Hasil IRF yang menggambarkan respon dinamis variabel tingkat inflasi $(\mathrm{D}(\mathrm{CPI}))$, tingkar harga perumahan (D(RPPI)), nilai tukar $(\mathrm{D}(\mathrm{ER}))$ dan output $(\mathrm{R}(\mathrm{GDP}))$ terhadap shock BI Rate ditunjukkan dalam gambar 2. 
Gambar 2 Impulse Response Function Shock BI Rate

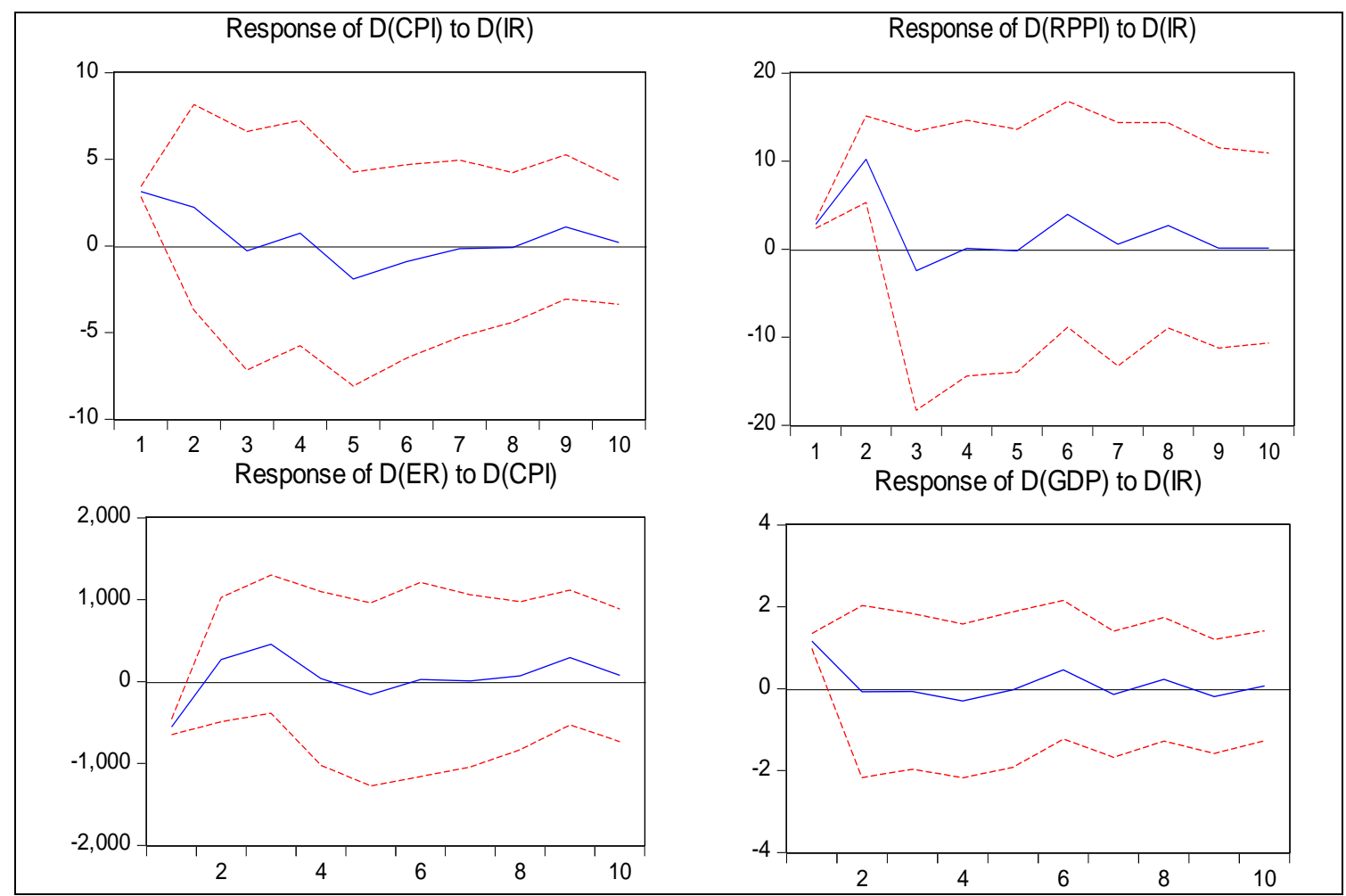

Sumber : hasil olah data

Respon tingkat inflasi terhadap shock positif satu standar deviasi variabel BI Rate pada periode triwulan ke 1 dan 2 menunjukkan respon positif, sedangkan pada periode triwulan ke 4 dan ke 5 tingkat inflasi relatif bergerak menuju keseimbangan. Kenaikan BI Rate baru dapat menyebabkan penurunan tingkat inflasi dimulai pada periode triwulan ke 5 (penurunan terendah) dan berlangsung sampai periode triwulan ke 8. Hasil uji struktural IRF pada respon tingkat harga perumahan terhadap shock satu standar deviasi variabel BI Rate menunjukkan respon positif pada periode awal (triwulan 1 dan 2). Penurunan tingkat harga perumahan akibat kenaikan variabel BI Rate terjadi pada periode triwulan ke 3 .

Respon nilai tukar terhadap perubahan satu standar deviasi positif variabel BI Rate pada awal periode yakni triwulan 1 menunjukkan respon negatif (penguatan Rupiah), sedangkan pada periode triwulan ke 2 dan ke 3 nilai tukar mengalami kenaikan dan pada periode triwulan ke 4 dan periode selanjutnya mengalami keseimbangan. Sedangkan untuk respon output terhadap perubahan BI Rate pada awal periode yakni triwulan 1 menunjukkan respon positif. Kenaikan BI Rate akan menurunkan output berlangsung pada periode triwulan ke 2 sampai triwulan ke 5 , dengan penurunan terendah pada periode triwulan ke 4.

Dalam pembahasan dampak BI Rate terhadap tingkat inflasi dan tingkat harga perumahan serta variabel makro lainnya analisa variance decomposition yang dilakukan menggunakan cholesky decomposition. Tabel 4.7 menunjukan persentase variasi variabel tingkat inflasi, harga perumahan, output dan nilai tukar terhadap shock variabel BI Rate.

Tabel 6 Variance Decomposition Shock BI rate

\begin{tabular}{ccccc}
\hline Periode & $\mathrm{D}(\mathrm{CPI})$ & $\mathrm{D}(\mathrm{RPPI})$ & $\mathrm{D}(\mathrm{ER})$ & $\mathrm{D}(\mathrm{GDP})$ \\
\hline 1 & 0.000000 & 3.529920 & 0.000000 & 0.005293 \\
\hline 2 & 7.492573 & 1.856708 & 6.927250 & 0.034866 \\
\hline 3 & 6.635505 & 1.999340 & 4.909029 & 0.151420 \\
\hline 4 & 7.753198 & 2.711246 & 3.617250 & 0.135670 \\
\hline 5 & 9.139244 & 2.710319 & 3.323675 & 0.336065 \\
\hline 6 & 10.04861 & 2.551849 & 3.286048 & 0.308291
\end{tabular}




\begin{tabular}{ccccc}
7 & 9.977260 & 2.655409 & 3.271095 & 0.431112 \\
\hline 8 & 10.02943 & 2.701219 & 3.162321 & 1.427506 \\
\hline 9 & 10.35817 & 2.787916 & 3.037437 & 1.428731 \\
\hline 10 & 10.35071 & 2.869451 & 3.259292 & 1.426531 \\
\hline
\end{tabular}

Sumber : hasil olah data

Hasil variance decomposition menunjukan bahwa shock BI Rate tidak memberikan kontribusi terhadap perubahan tingkat inflasi pada periode triwulan ke 1. Namun pada triwulan ke 2 shock BI Rate memberikan kontribusi sebesar $7.49 \%$ terhadap tingkat inflasi dan cenderung meningkat hingga mencapai $10.35 \%$ pada akhir periode observasi. Hasil analisa untuk pengaruh BI Rate terhadap tingkat harga perumahan menunjukkan shock BI Rate relatif kecil dalam mempengaruhi tingkat harga perumahan, dengan kontribusi berkisar 1.85\%-2.86\%. Pada triwulan ke 1 shock BI Rate memberikan kontribusi sebesar 3.53\% (kontribusi tertinggi) terhadap harga perumahan namun berkurang pada periode-periode selanjutnya. Untuk pengaruh BI Rate terhadap nilai tukar, hasil variance decomposion menunjukkan pada periode triwulan ke 1 tidak ada kontribusi BI Rate terhadap perubahan nilai tukar. Pada triwulan ke 2 shock BI Rate memberikan kontribusi sebesar $6.49 \%$ terhadap nilai tukar dan terus menurun pada periodeperiode selanjutnya hingga mencapai 3.25\% pada akhir periode observasi. Sedangkan hasil variance decomposition untuk pengaruh BI Rate terhadap output relatif sangat kecil yaitu sekitar $0.005 \%-1.42 \%$, walaupun kontribusinya terhadap output cenderung terus meningkat.

\section{Kesimpulan}

Struktural Vector Autoregression (SVAR) dikembangkan dalam penelitian ini untuk mengidentifikasi respon dan dampak kebijakan moneter di Indonesia terhadap inflasi dan harga perumahan. Hasil estimasi menunjukkan kebijakan moneter yang dilakukan oleh Bank Indonesia melalui perubahan BI Rate menunjukkan respon yang cepat terhadap shock variabel inflasi, output dan nilai tukar. Namun kebijakan moneter yang selama ini dilakukan tidak merespon terhadap perubahan harga perumahan. Penggunaan instrumen makroprudential loan to value (LTV) yang telah diterapkan oleh Bank Indonesia diharapkan dapat meminimalkan risiko terjadinya bubble harga perumahan. Namun mempertimbangkan besarnya potensi instabilitas sistem keuangan yang diakibatkan oleh harga perumahan, stance kebijakan moneter yang dilakukan oleh Bank Indonesia melalui perubahan suku bunga perlu merespon terhadap fluktuasi harga perumahan.

Model yang dikembangkan dalam penelitian ini mengindikasikan kurang efektifnya transmisi kebijakan moneter. Penyempurnaan kerangka operasional kebijakan moneter untuk meningkatkan efektivitas transmisi kebijakan moneter perlu dilakukan oleh Bank Indonesia. Penggunaan suku bunga acuan baru yang ditetapkan oleh Bank Indonesia yaitu BI 7 days reverse repo rate yang berlaku efektif sejak 19 Agustus 2016 untuk menggantikan BI Rate sebagai suku bunga acuan di pasar uang antar bank dapat dibenarkan. Dengan tenor BI 7 days reverse repo rate yang pendek diharapkan transmisi kebijakan moneter dapat berjalan lebih cepat dan efektif.

Diperlukan penelitian lebih lanjut untuk memperoleh hasil yang robust, penetapan restriksi atas model SVAR yang dikembangkan dapat dikaji lebih lanjut dan kemungkinan penggunaan restriksi jangka pendek dan jangka panjang secara bersamaan dalam model SVAR. Serta kemungkinan perlunya menginternalisasi variabel penting lainnya ke dalam model untuk memberikan hasil yang lebih akurat.

\section{Daftar Pustaka}

Ahearne, Alan G, John Ammer, Brian M. Doyle, Linda S. Kole, Robert F. Martin, 2005, "Monetary Policy and House Prices: A Cross-Country Study," International Finance Discussion Papers 841, Board of Governors of the Federal Reserve System (U.S.).

Akram, Q. F., Bärdsen, G. and Eitrheim, Ø (2006), "Monetary policy and asset prices: to respond or not?," International Jurnal of Finance and Economics, 11: 279-292.

Aoki, Kosuke, James Proudman dan Gertjan Vlieghe, 2002, "Houses as Collateral: Has the Link Between House Prices and Consumption in the U.K. Changed?," Economic Policy Review, Federal Reserve Bank of New York, issue May, pages 163-177.

Bjørnland, Hilde and Dag Henning Jacobsen, 2010, "The Role of House Prices in The Monetary Policy Transmission Mechanism in Small 
Open Economies," Journal of Financial Stability, Volume 6, Issue 4, pages 218-229.

Borio, Claudio, dan Haibin Zhu (2012), "Capital regulation, Risk-taking and Monetary Policy: A Missing Link in The Transmission Mechanism?," Journal of Financial Stability, Volume 8, Issue 4, December 2012, pages 236-251.

Borio, Claudio and Phillip Lowe (2002) "Asset Prices, Financial and Monetary Stability: Exploring the Nexus," BIS Working Paper No. 114, July.

Cecchetti, Stephen G., Hans Genberg, John Lipsky and Sushil Wadhwani (2000), "Asset Prices and Central Bank Policy," Geneva Report on the World Economy 2.

Pariès, Matthieu Darracq and Alessandro Notarpietro (2008), "Monetary Policy and Housing Prices in an Estimated DSGE for The US and The Euro Area," Working Paper Series 0972, European Central Bank.

Elbourne, Adam (2008), "'The UK Housing Market and The Monetary Policy Transmission Mechanism: An SVAR approach," Journal of Housing Economics, Elsevier, vol. 17(1), pages 65-87, March.

Enders, Walter (2003), “Applied Econometric Time Series", Iowa State University.

Filardo, Andrew J. (2004) "Monetary Policy and Asset Price Bubbles: Calibrating the Monetary Policy Trade-Offs," BIS Working Paper No. 155, June.

Iacoviello, M and Raoul Minetti (2008), "The Credit Channel of Monetary Policy: Evidence from The Housing Market," Journal of Macroeconomics, 30 (1), 69-96.

Lastrapes, WD (2002), "The Real Price of Housing and Money Supply Shocks: Time Series Evidence and Theoretical Simulations," Journal of Housing Economics, 11 (1), 40-74.

McDonald, J. and Houston H. Stokes, H (2015), "Monetary Policy, Fiscal Policy, and The Housing Bubble," Modern Economy, 6, 165178.

Jarociński, Marek and Frank R. Smets (2008), "House Prices and The Stance of Monetary Policy," Working Paper Series 0891, European Central Bank.

Kivedal, Bjørnar Karlsen (2013), “Testing for Rational Bubbles in the US Housing Market," Journal of Macroeconomics, Elsevier, vol. 38(PB), pages 369-38.

Kontikas, Alexandros and Alberto Montagnoli (2004), "Optimal Monetary Policy and Asset
Price Misalignments," Money Macro and Finance Research Group.

Liu, Henry J. and Chunlu Liu (2012), "Investigating the Housing Market Fluctuation Under an Expansionary Monetary Policy in Australia," Pacific Rim Property Research Journal, vol. 18, no. 1, pages 81-89.

McCarthy, Jonathan and Richard W. Peach (2002), "Monetary Policy Transmission to Residential Investment," Federal Reserve Bank of New York, Economic Policy Review, vol. 8 (no.1), pages 139-58.

Mishkin, Frederick (2007), "Housing and the Monetary Transmission Mechanism," NBER Working Papers 13518, National Bureau of Economic Research, Inc.

Phiri, Andrew (2016), "Asymmetric Pass-Through Effects from Monetary Policy to Housing Prices in South Africa," MPRA Paper 70258, University Library of Munich, Germany.

Sá, Filipa, Pascal Towbin and Tomasz Wieladek (2011), "Low Interest Rates and Housing Booms: The Role of Capital Inflows, Monetary Policy and Financial Innovation," Globalization and Monetary Policy Institute Working Paper 79, Federal Reserve Bank of Dallas.

Sims, Christopher A (1986), "Are Forecasting Models Usable for Policy Analysis?," Federal Reserve Bank of Minneapolis Quarterly Review. Winter, pages $2-16$.

Tan, Zhengxun and Ming Chen (2013), "House Prices as Indicators of Monetary Policy: Evidence from China," Working Paper No. 488, Stanford Centre for International Development.

Taylor, John B. (1993), "Discretion versus Policy Rules inPractice," Carnegie-Rochester Conference Series on Public Policy. 39: 195-214.

Taylor, John. B. (2007), "Housing and Monetary Policy,” NBER Working Paper No. w13682. Vargas-Silva, C (2008), "Monetary Policy and The US housing market: A VAR Analysis Imposing sign restrictions," Journal of Macroeconomics, 30 (3), 977-990.

Zhu, Min (2014), "Housing Markets, Financial Stability and The Economy," Opening Remarks at the Bundesbank/German Research Foundation/IMF Conference. 